\title{
Um sítio da tradição cerâmica Aratu em Apucarana, PR*
}

\author{
Pedro Ignácio Schmitz** \\ Jairo Henrique Rogge**
}

SCHMITZ, P.I.; ROGGE, J.H. Um sítio da tradição cerâmica Aratu em Apucarana, PR. Revista do Museu de Arqueologia e Etnologia, São Paulo, 18: 47-68, 20008.

Resumo: $O$ texto descreve um sítio arqueológico descoberto na cidade de Apucarana, PR, no qual predominam elementos Aratu como eles foram estudados no Brasil Central, mas estão presentes também importantes elementos da tradição Itararé, como ela aparece no sul do Brasil. O sítio encontra-se em alta colina que divide as águas dos rios Tibagi, Pirapó e Ivaí, afluentes do rio Paranapanema. Em ambiente de clima subquente, com precipitação atmosférica de $1.500 \mathrm{~mm}$, solos ricos, cobertos por Floresta Tropical Semidecídua, vizinhando com Floresta Subtropical decídua com Araucaria angustifolia. Por AMS, o sítio foi datado do século XIV/XV de nossa era, data que corresponde ao período em que a tradição Aratu tinha criado núcleos de povoamento no Nordeste, no Centro-oeste, no Sudeste e no Sul do país, em áreas de Mata Atlântica, enclaves florestados dentro do cerrado e áreas de tensão ecológica na floresta tropical. Para deixar clara a posição do sítio, o trabalho recapitula as informações mais importantes da tradição Aratu.

Palavras-chave: Apucarana - Sítio Aratu - Contato Itararé.

\section{Introdução}

\begin{abstract}
s primeiras pesquisas regulares sobre - sítios da tradição cerâmica Aratu foram realizadas em áreas de clima quente, no litoral e no interior da Bahia, em Goiás e em
\end{abstract}

$\left(^{*}\right)$ Os autores agradecem a Osvaldo Paulino da Silva, Miriam Carle e Rogério Carle, que fizeram o trabalho de campo, a primeira análise e o relatório técnico, e deixaram todo o material e documentação sob a guarda do Instituto Anchietano de Pesquisas. Agradecem a Fúlvio Vinicius Arnt o apoio na leitura do texto e das ilustrações. $\left({ }^{* *}\right)$ Instituto Anchietano de Pesquisas/UNISINOS. Schmitz<anchietano@unisinos.br>;

Rogge<rogge@unisinos.br>
Minas Gerais. Posteriormente foram estudados sítios no norte, nordeste e leste de São Paulo, em ambientes ainda parecidos. A recente descoberta de um grande assentamento Aratu em Apucarana, no norte do Estado do Paraná, no limite da Floresta tropical com a Floresta subtropical com presença de Araucaria angustifolia, mostra que a população dessa tradição cerâmica teve maior expansão e maior adaptabilidade ambiental do que parecia inicialmente, ocupando desde a densa floresta do litoral do Nordeste e Centro, a enclaves florestados em meio ao cerrado do Nordeste e do Brasil Central, até a floresta tropical do interior de São Paulo e do norte do Paraná. Seu território confrontava com o de outras populações, que muitas vezes competiam 
pelos mesmos ambientes. O contato com essas populações resultou em sítios em que, além dos materiais da tradição cerâmica Aratu, estão presentes cerâmicas da tradição Tupiguarani, da tradição Uru, ou da tradição Taquara/ Itararé. No sítio de Apucarana, o abundante material cerâmico da tradição Aratu vem acompanhado de certo volume de elementos da tradição Taquara/Itararé, que dominava o Planalto Meridional. O intercâmbio de tecnologias na fabricação tanto da cerâmica, quanto do lítico, sugere a convivência nessa última aldeia de pessoas de duas populações diferentes.

O sítio localiza-se dentro da cidade de Apucarana, na encosta de suave colina, a $785 \mathrm{~m}$ de altitude, junto às nascentes do rio Pirapó, no divisor de águas entre os rios Tibagi e Ivaí.

Por enquanto Apucarana é um assentamento isolado num ambiente em que convergem formações florestais variadas, representativas do Planalto Central, do Planalto Meridional e da Bacia do rio Paraná. Ele está longe da principal área de povoamento da tradição Aratu e próximo da área dominada pela tradição Taquara/Itararé. Ainda não se conhece nos arredores nenhum sítio desta tradição meridional, mas ao longo dos rios antes mencionados foram localizados assentamentos da tradição Tupiguarani.

O texto começa com um panorama da tradição cerâmica Aratu, buscando uma moldura para o sítio e a problemática desta instalação. Depois apresenta o sítio e o resgate do material e descreve a cerâmica e os artefatos líticos. As considerações finais procuram caracterizar o assentamento e sua posição no povoamento da área.

\section{A tradição Aratu}

A tradição cerâmica Aratu foi estabelecida pelo PRONAPA (Programa Nacional de Pesquisas Arqueológicas) a partir de trabalho realizado por Valentin Calderón, na Bahía. O nome foi dado em atenção à cidade industrial de Salvador, na qual foram encontrados sítios representativos (Brochado et al. 1969).
Pesquisas sobre a tradição foram feitas na Bahía (Calderón 1969, 1971, 1974; Fernandes 2003), no Espírito Santo (Perota 1971, 1974), em Minas Gerais, com o nome de tradição Sapucaí (Dias Jr. 1971); no Tocantins (Oliveira 2005; Morales 2005); em Goiás (Schmitz et al. 1982; Wüst 1983; Schmitz \& Barbosa 1985, Robrahn-González 1996; Viana 1996; 2004); em São Paulo (Maranca, Silva \& Scabello 1994; Alves \& Cheuiche Machado 1995/96; Alves \& Calleffo 1996; Robrahn-González et al. 1998; Caldarelli 1999, 2003; Gomes 2003; Alves 2003, 2004; Afonso \& Moraes 2005/2006).

A tradição identifica uma população agrícola, com grandes e duradouros sítios habitacionais, em que poderiam morar até mais de mil pessoas, junto aos quais podem ser encontrados cemitérios contendo até uma centena de urnas funerárias. Sítios atribuídos a essa tradição vêm sendo encontrados no Nordeste, Centro, Sudeste e Sul do Brasil, em áreas de clima quente a sub-quente, com solos suficientes para agricultura, cobertas por florestas, regadas por abundantes chuvas anuais, mesmo se estas são interrompidas por diversos meses secos; instalação preferencial em interflúvios, na proximidade de córregos e rios menores, em relevo suave a medianamente ondulado. (cf. Geografia do Brasil 1977, passim).

Eles foram registrados em diversos locais da costa da Bahía, de Sergipe, de Alagoas e do Espírito Santo, em áreas de clima quente e superúmido, sem mês de seca, cobertas por Floresta perenifolia higrófila; no interior da Bahía, do Piauí, do Tocantins, do norte e sudeste de Goiás, em áreas de clima quente, semi-úmido com vários meses de seca, cobertas por Floresta tropical semi-decídua, formando enclaves em áreas de cerrado; também no sul de Minas Gerais, no norte, nordeste e leste de São Paulo e, com o novo sítio aqui descrito, também no norte do Paraná, em áreas de clima quente a sub-quente, úmido, cobertas por Floresta tropical semidecídua, com presença, ou na proximidade de Cerrados. Das áreas em que predomina o Cerrado parecem ter sido aproveitados para assentamento os maiores enclaves florestados, na verdade ricas áreas de tensão ecológica, que lhes proporcionariam o domínio simultâneo de um 
variado gradiente ambiental. Nas áreas de Floresta tropical semi-decídua do Sudeste e Sul, a proximidade de enclaves de Cerrado parece ter sido igualmente importante para estabelecer assentamentos. A proximidade do sítio de Apucarana com a floresta de Araucária pode não ser casual: na ausência de maior quantidade de frutos do cerrado, o pinhão no outono complementaria bem os cultivos de primaveraverão. Nos grupos estabelecidos ao longo da costa atlântica, a relação com o ambiente provavelmente não seria a mesma e outros recursos poderiam complementar os cultivos (Figs. 1 e 2).

No limite com todos esses ambientes e culturas deveriam existir tensões fronteiriças, que poderiam ser belicosas ou pacíficas. Na bibliografia da tradição Aratu foram registrados diversos fenômenos de fronteira: com populações da tradição Tupiguarani eles foram registrados no Espírito Santo, na Bahía, em Goiás, em Minas Gerais e em São Paulo; com populações da tradição Uru, foram registrados em Goiás, no Tocantins e em São Paulo; com populações Jê do Planalto Meridional resultaram contatos no Paraná (o sítio em análise) e no sul de Minas Gerais, onde, na fase Jaraguá, aparece uma casa subterrânea. Que tipo de relações haveria entre as populações da tradição Aratu e as da tradição Una, nos cerrados de Goiás e Minas Gerais, é mais difícil de estabelecer pela semelhança existente entre as cerâmicas dessas duas tradições. Limites territoriais costumam originar sítios em que elementos de mais de uma cultura aparecem juntos, mas não é fácil desvelar os processos que os originaram, as

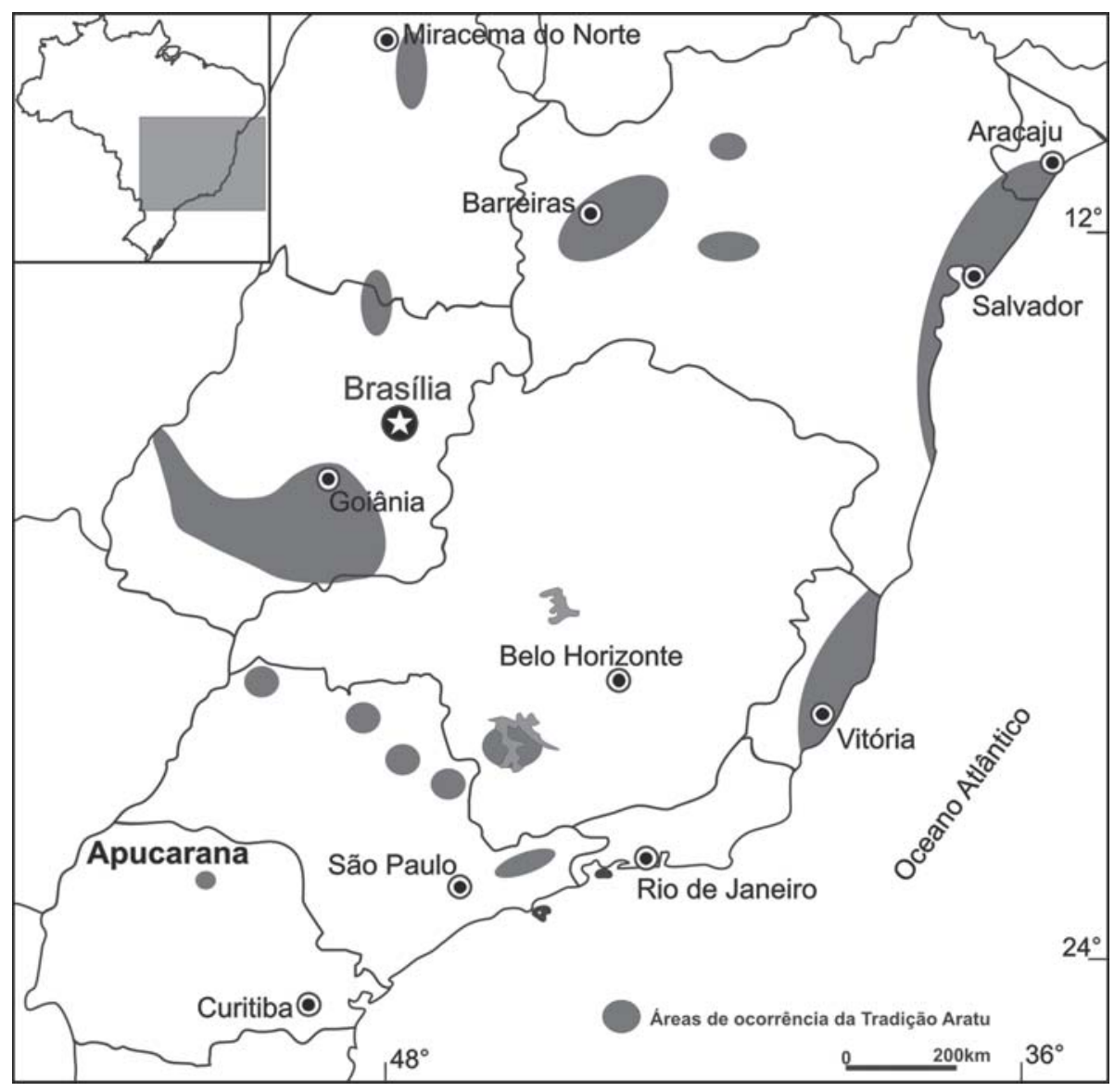

Fig. 1. Áreas de ocorrência da tradição Aratu. 


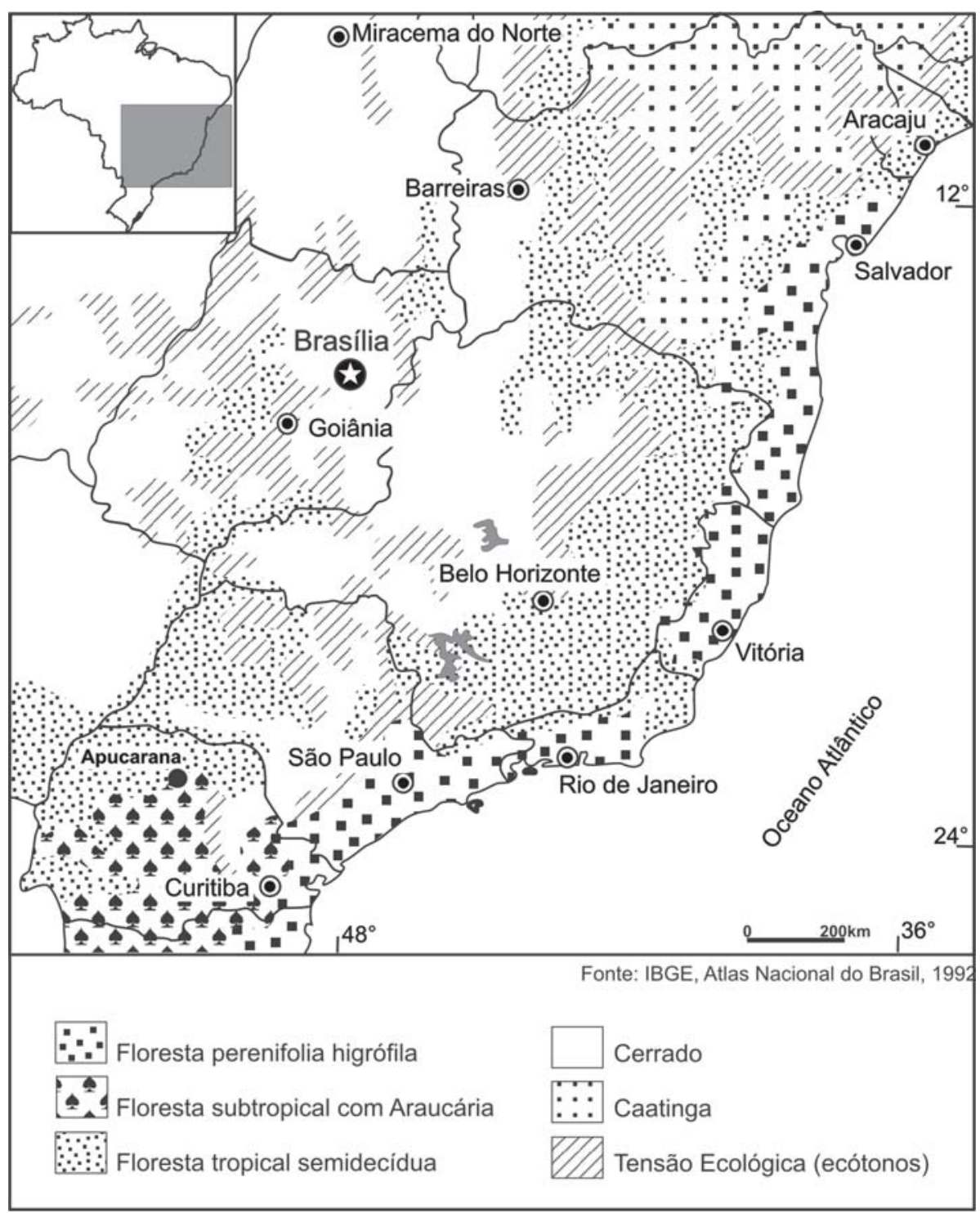

Fig. 2. Vegetação original da área em que se instalou a tradição Aratu. Compare com o mapa da Fig. 1.

relações que surgiram e a intensidade que assumiram (Rogge 2005; Souza 2005).

Nos sítios, a cerâmica costuma ser abundante, com variedade de formas e tamanhos, como nos outros grandes grupos agricultores brasileiros. Na preparação da pasta, além da argila, de acordo com a região, eram usados elementos minerais (areia quartzosa, hematita, grafite, mica) e vegetais (algum tipo de cariapé). $\mathrm{O}$ vasilhame compreende jarros piriformes, ou globulares, com até $75 \mathrm{~cm}$ de altura e $60 \mathrm{~cm}$ de diâmetro; panelas grandes, médias e pequenas, com bordas inflectidas, mas sem reforços; tigelas de vários tamanhos, com bordas diretas, às vezes acasteladas; pequenos vasos geminados, muito característicos; recipientes com bases de múltiplos furos, realizados enquanto a pasta estava fresca. As superfícies externas desse vasilhame são alisadas, algumas vezes engobadas ou com pintura vermelha, com uma incisão, um entalhe, um rolete não obliterado, uma fila ou faixa de corrugados junto à borda. Raramente aparecem 
pequenos apêndices mamilonares, em botão ou asa. Esta cerâmica não se confunde com a de populações agrícolas vizinhas, que são a Uru e a Tupiguarani, nem com a cerâmica da tradição Una e da tradição Itararé, de populações nas quais o cultivo é menos desenvolvido e a caça e a coleta são mais aparentes.

O material lítico se compõe de seixos percutores, quebra-cocos, polidores, raspadores laterais, lâminas polidas de machado com garganta ou semi-lunares, mãos-de-pilão picoteadas e martelos, talhadores lascados e lascas com algum retoque ou usadas diretamente. As lâminas em forma de meia-lua são abundantes nos sítios do sudeste de Goiás, mas não é claro se podem ser tomadas como identificadoras da tradição.

Já existe certo número de datas que permitem pensar a expansão da tradição e as cronologias regionais. $\mathrm{Na}$ Bahía os sítios apresentam cinco datas de C-14, entre 1080 +. 90 AP (SI$542)$ e 590 +- 50 AP (SI-541). No Espírito Santo há três datas de C-14 para a tradição Aratu: 600 +. 45 AP (SI-1186), 470 +-80 AP (SI-1188) e 350 + 60 AP (SI-1187). Em Minas Gerais os sítios, inicialmente atribuídos à tradição Sapucaí, estão datados por C-14 em 855 +. 90 AP (SI-822) e 855 +. 70 AP (SI-824). Em Goiás, onde os numerosos sítios se apresentam como grandes aldeias, 15 datas de C-14 formam uma seqüência de 1220 + 50 AP (Beta 99031) a 480 +- 50 AP (Beta 92530); existem ainda duas datas maiores, cujo significado é menos claro: 1650 +. 50 anos A.P. (Beta 92528) e 2280 + 60 anos A.P. (Beta 92529). No Médio Tocantins a única data de C-14 é 780 anos A.P. (Morales 2005).

Segundo Afonso e Moraes (2005-2006), em São Paulo são conhecidos os seguintes sítios: Maranata (Olímpia), Água Limpa (Monte Alto), Água Branca (Casa Branca), Lagoa Preta I, Lagoa Preta II, Tamanduazinho (São Simão) na bacia do Rio Grande; Cachoeira das Emas I, na bacia do rio Mogi Guaçu, e Caçapava I e Light na bacia do rio Paraíba do Sul. Gaspar, Barbosa \& Cordeiro (2007) acrescentaram, nessa bacia, um sítio em Aparecida, um em Natividade da Serra e um em São José dos Campos. Água Limpa, em Monte Alto, foi intensamente datada, não por C-
14, mas por TL, na USP: na Zona 1, as datas vão de $1524+$ + 212 a $460+.50$ anos AP (Alves 2004: 315). A média das 10 datas seria 1035 +. 148 anos AP, uma data compatível com as antigas da seqüência de Goiás. Na zona 2, as datas vão de 890 +. 90 a $335+35$ anos AP (Alves 2004:315). A média dessas 10 datas seria de $582+.58$ anos AP, uma data compatível com ocupações recentes da tradição Aratu em outros estados brasileiros. Em São Paulo temos ainda cinco datas de C-14 do sítio de Caçapava I, que vão de 870 +. 40 a 590 + 50 anos AP (Caldarelli 2003). Há também duas datas no sítio Água Vermelha, uma de 1010 +50 e outra de $700+.70$ anos A.P. (Afonso \& Moraes 2005-2006).

As datas disponíveis sugerem ocupações antigas tanto na Bahia, como no sudeste de Goiás e no norte/nordeste de São Paulo. E uma continuidade de ocupação, nas diversas áreas, até a conquista européia, apesar do avanço de outras populações nos limites de seu território no leste, no oeste e no sul.

O sítio de Apucarana, com sua data de 590 +- 40 anos AP (Beta 238714) é, por enquanto, o ponto mais avançado para o Sul, já no limite com a fria Floresta subtropical com Araucaria angustifolia.

As datas nos dão poucas informações sobre a origem da tradição e a especulação sobre a mesma ainda não produziu resultados confiáveis (Brochado 1984). Acredita-se que a população teria pertencido ao tronco lingüístico Jê e que, no Planalto Central, os Kaiapó do Sul poderiam ser representantes coloniais (Ataídes 1991, ver também mapa de Peret 1971 e de Nimuendajú 1980).

\section{O sítio e a recuperação do material}

Os dados para a descrição do sítio foram retirados do Relatório Final de Pesquisa do Projeto de Avaliação e Salvamento Arqueológico na Área do Empreendimento Imobiliário Residencial Interlagos. Apucarana/Paraná, assinado por Osvaldo Paulino da Silva, Florianópolis, dezembro de 2001 (Fig. 3).

A história da identificação do sítio reporta-se aos últimos oito anos anteriores a 


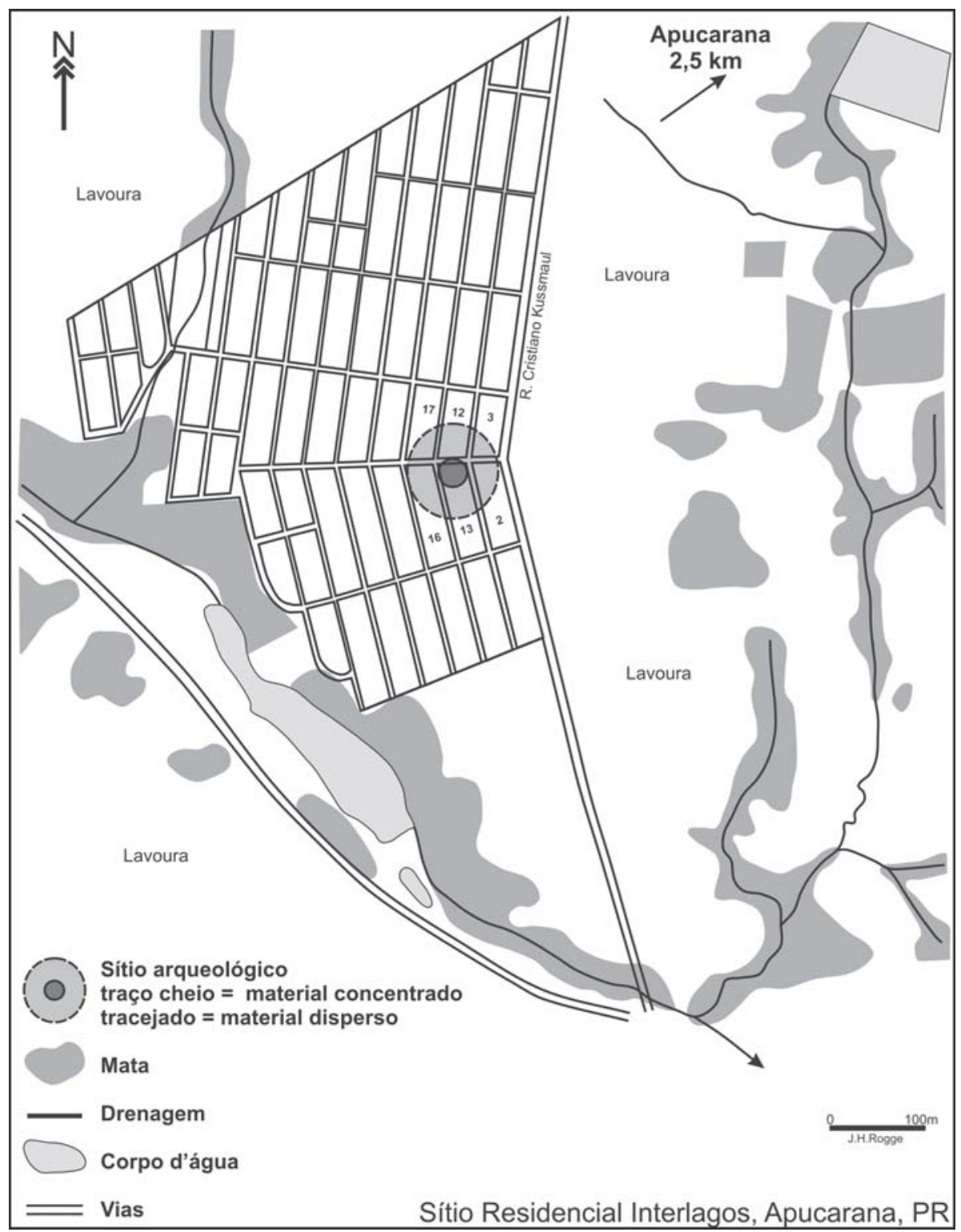

Fig. 3. A implantação do sítio arqueológico no ambiente e sua posição no Empreendimento Imobiliário Residencial Interlagos.

2001, quando professores e alunos da escola estadual Santos Dumont, localizada na cidade de Apucarana, começaram a recolher fragmentos cerâmicos e alguns artefatos líticos numa antiga área de reflorestamento com eucalipto.

A análise original do material cerâmico, bem como a elaboração do relatório respectivo, foram executadas pela arqueóloga Miriam Carle e pelo estagiário Rogério Carle. A coordenação geral dos trabalhos foi do arqueólogo Ms. Osvaldo Paulino da Silva.

O terreno possui topografia ondulada. Ele abrange antigas áreas agrícolas, utilizadas exaustivamente no ciclo do café. O centro do sítio encontra-se a $785 \mathrm{~m}$ de altitude, na alta vertente de uma colina suave. Localização geográfica: 23॰34’25.10S e 51॰29'10.62W. 
O levantamento foi executado através de um rastreamento superficial, orientado por transects, ou seja, linhas de caminhada distantes $10 \mathrm{~m}$ uma da outra. Na área de maior concentração de material arqueológico procedeu-se, inicialmente, a uma coleta assistemática do material de superfície.

Inicialmente fez-se uma coleta aleatória dos vestígios cerâmicos dispersos pelas áreas próximas à quadra 13, que são as quadras 2, 3, 12, 16 e 17.

Depois, quadriculou-se a quadra 13 e efetivou-se uma coleta sistemática de todos os vestígios dispersos superficialmente. Este núcleo central tem aproximadamente $50 \mathrm{~m}$ de diâmetro (Fig. 3).

O resultado dos trabalhos apontou a inexistência de qualquer vestígio arqueológico relevante, em superfície ou em profundidade, na área do empreendimento fora da quadra 13 , local onde foi identificado o sítio cerâmico.

Com autorização do IPHAN, todo o material, junto com o relatório, ficaram depositados no Instituto Anchietano de Pesquisas, onde o material foi novamente submetido a análise parcial, de que resultou esta publicação.

A retomada da análise mostra que se trata, realmente, de um sítio da tradição Aratu como ela é conhecida do Planalto Central (Schmitz et al. 1982; Wüst 1983; Robrahn-González 1996), com elementos da tradição Itararé, como é conhecida no Planalto Meridional (Schmitz 1988).

A aldeia estava instalada num ponto alto que divide os rios Pirapó, Tibagi e Ivaí, junto às nascentes do rio Pirapó, mas sobre um afluente do rio Ivaí, em solo rico (terra roxa), proveniente da decomposição de basalto, coberto por densa Floresta tropical semidecidual. Vizinhava com a Floresta subtropical semidecidual com Araucaria angustifolia na qual ainda sobram quatro áreas disjuntas de Cerrado: o Cerrado do Vale do Rio das Cinzas, no nordeste do estado, o Cerrado Norte Velho, na margem direita do rio Tibagi, o Cerrado Norte Novo, composto por pequenos fragmentos ilhados em meio à Floresta estacional semidecidual, na proximidade de Maringá (e de Apucarana) e o Cerrado de Campo Mourão (Linsinger \& Cervi 2008).

O clima da região é considerado subquente, superúmido, sem marcado período seco. $\mathrm{Na}$ classificação de Koepen é Cfa de altura, com temperatura média anual ao redor de $21^{\circ} \mathrm{C}$, a do mês mais quente ao redor de $24^{\circ} \mathrm{C}$ e a do mais frio ao redor de $17^{\circ} \mathrm{C}$, com rara ocorrência de geadas noturnas. As chuvas se distribuem por todo o ano, num total de aproximadamente $1500 \mathrm{~mm}$, sendo o mês mais chuvoso janeiro, e julho o de menor precipitação.

O grosso fundo de uma grande panela da tradição Aratu, no qual havia incrustação de restos alimentares, que tinham penetrado até a metade da parede, foi datado, por AMS, em 590 +. 40 anos AP, idade radiocarbônica tradicional (Beta-238714), calibrada com 2 sigmas em AD 1290 a 1420 (Cal AP 660 a 530). Esta data pode ser tomada como referência para situar o assentamento de Apucarana com relação aos outros assentamentos da tradição Aratu.

O material da coleção, composto por milhares de fragmentos cerâmicos e alguns objetos líticos, indica que se tratava de uma aldeia bastante grande. Os objetos vêm das coletas superficiais assistemáticas iniciais, cobrindo toda a área, e de coletas sistemáticas, na área central quadriculada, feitas por Osvaldo Paulino da Silva e seus auxiliares, conforme foi referido anteriormente. Nestas coletas a quase totalidade da cerâmica se compõe de fragmentos pequenos que, sem o material da escola, seriam insuficientes para o estudo e a reconstituição das peças. Mas, também nessas coleções existem numerosos fragmentos de bordas, que tornaram o trabalho bem rico. Ao todo foram desenhadas 285 bordas, uma excelente amostragem para caracterizar a cerâmica de um sítio.

\section{A cerâmica}

\subsection{As formas da cerâmica}

No conjunto dos 10.240 fragmentos cerâmicos é possível separar grandes categorias de formas (Figs. 4 e 5):

A) Recipientes grandes, panelas, com borda direta, constrição na boca, lábio arredondado ou aplanado, base convexa, arredondada, corpo sub-globular ou levemente ovóide, abertura da 

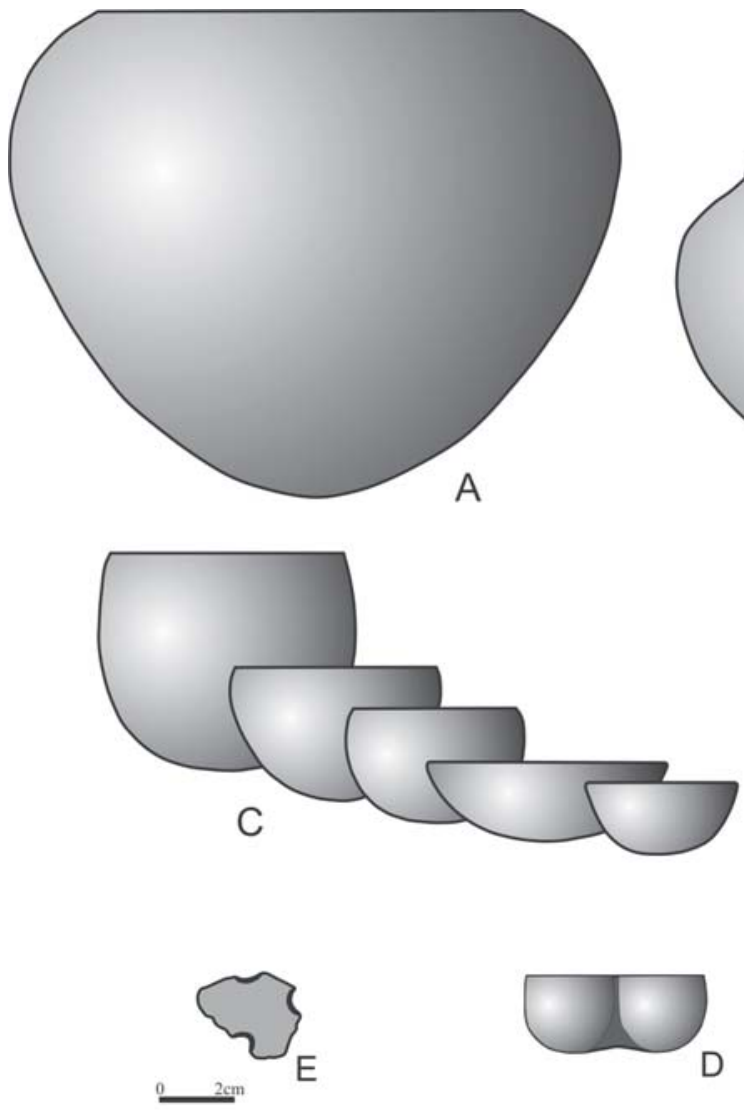
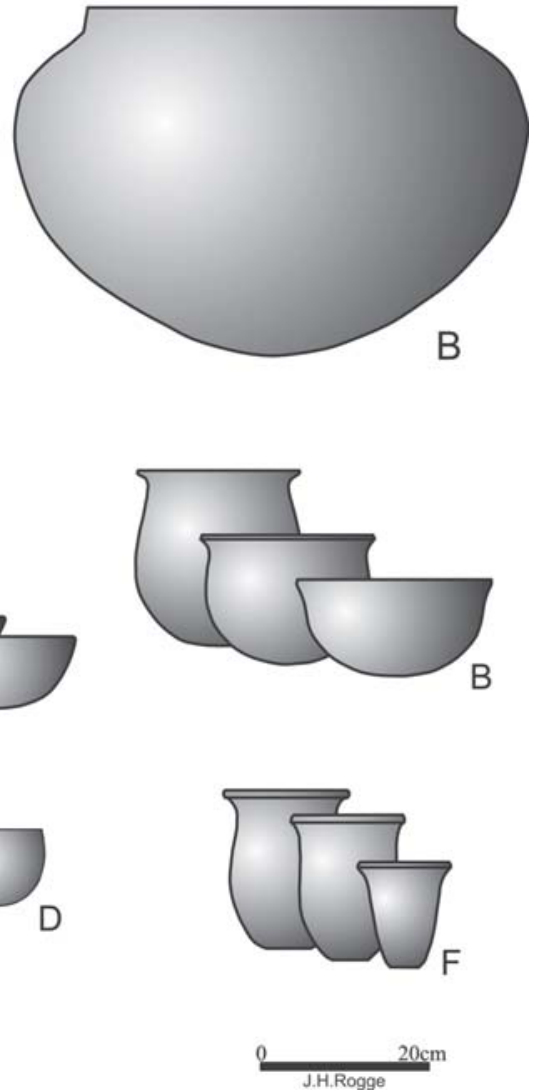

Fig. 4. Os conjuntos cerâmicos do sítio: formas A-E, da tradição Aratu; forma F, da tradição Itararé.

boca 34 a $58 \mathrm{~cm}$; às vezes apresenta desgaste na face interna junto da boca proveniente de uso, ao mexer no interior. Pasta com grande quantidade de grãos de hematita, às vezes também algum cariapé. Usados para preparar alimentos cozidos como indicam o escurecimento e os resíduos na face interna da base. São oito bordas medidas (Tabela 1).

B) Recipientes grandes, médios e pequenos, classificados como panelas, com borda inflectida, não reforçada, corpo sub-globular, sub-cilíndrico, ou ovóide, constrito na altura da inflexão, base convexa, arredondada, lábio predominantemente arredondado, mais raramente aplanado ou em bisel, abertura de boca de 8 a $50 \mathrm{~cm}$. Os recipientes eram usados para preparar alimentos cozidos, como indicam o escurecimento e os resíduos na face interna da base. Pasta com grande quantidade de grãos arredondados de hematita, às vezes também com a presença de cariapé esparso. São 136 bordas, das quais 68 foram medidas (Tabela 1).

C) Recipientes grandes, médios e pequenos, tigelas, em semi-esfera ou calota de esfera, com borda um pouco introvertida, vertical, ou extrovertida, não reforçada, lábios arredondados, raramente aplanados, base convexa, levemente arredondada, abertura da boca de 6 a $42 \mathrm{~cm}$. Pasta com denso cariapé bem fino, semelhante ao cariapé A dos sítios de Goiás (cf. Schmitz e outros 1982; Wüst 1983; RobrahnGonzález 1996), muitas vezes com alguns grãos de hematita. Paredes bastante finas. São 124 bordas medidas (Tabela 1). 

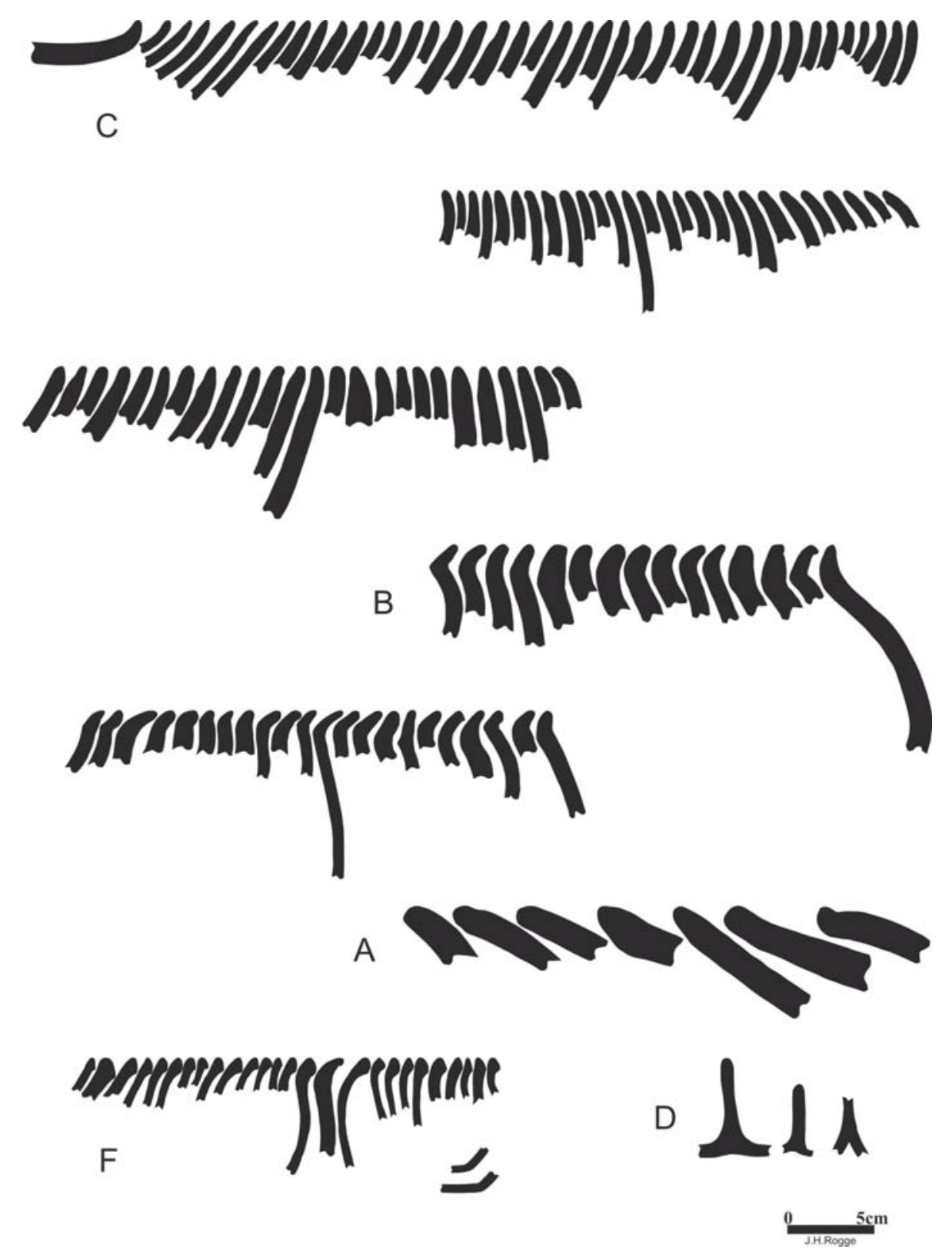

Fig. 5. As bordas da cerâmica do sítio: A-D da tradição Aratu; F da tradição Itararé.

D) Formas duplas, pequenas, com borda direta, aproximadamente vertical, lábio arredondado, base convexa arredondada. Pasta com denso cariapé. Total: 4.

E) Fragmento com perfurações feitas enquanto a pasta estava moldável. Pasta com cariapé. Total: 1.

F) Recipientes, geralmente pequenos, altos e delgados, borda levemente inflectida, lábio biselado com pequeno reforço, forma ovóide ou sub-cônica, base plana, aberturas da boca de 8 a $28 \mathrm{~cm}$, típicas formas itararé. Pasta com denso cariapé, cariapé com grãos de hematita, ou areia quartzítica angulosa, produzindo pastas equivalentes. Paredes geralmente finas: entre 6 e $22 \mathrm{~cm}$. São 25 bordas. Nota-se a predominância de aberturas ao redor de $12 \mathrm{~cm}$ (Tabela 1 ). 
Tabela 1

\begin{tabular}{ccccr}
\hline \multicolumn{5}{c}{ Aberturas da boca do vasilhame do sítio } \\
\hline $\begin{array}{c}\text { Aberturas } \\
\text { (em cm) }\end{array}$ & Forma A & Forma B & Forma C & Forma F \\
\hline \hline 6 & & & 1 & 2 \\
8 & & 2 & 3 & 2 \\
10 & & 5 & 4 & 3 \\
12 & & 5 & 5 & 12 \\
14 & & 5 & 7 & 2 \\
16 & & 5 & 16 & 1 \\
18 & & 7 & 14 & 2 \\
20 & & 3 & 13 & \\
22 & & 6 & 5 & 1 \\
24 & & 4 & 5 & \\
26 & & 3 & 9 & \\
28 & & 3 & 7 & \\
30 & & 1 & 19 & \\
32 & & 1 & 3 & \\
34 & 1 & 4 & 4 & \\
36 & & 3 & 3 & \\
38 & & & 3 & \\
40 & & 4 & 2 & \\
42 & 3 & & 1 & \\
44 & & 2 & & \\
46 & 1 & 1 & & \\
48 & 1 & 2 & & \\
50 & & 2 & & \\
52 & & & & \\
54 & 1 & & & \\
56 & & & & \\
58 & 1 & & & \\
TOTAL & 8 & & & \\
\hline
\end{tabular}

Chmyz 1977:64) e o litoral de Santa Catarina (p. ex. Schmitz 1988: 109 e Schmitz et al. 1993).

A espessura das paredes também pode ser usada para inferir o tamanho do vasilhame, porque costuma ser proporcional ao tamanho. Sem considerar diferenças no antiplástico, foram realizadas medições de todos os fragmentos das seguintes amostras: coleta superficial inicial, com 256 fragmentos; coleta da quadra 2, com 239 fragmentos; da quadra 3, com 199 fragmentos; da quadrícula 27Q-27R da quadra 13, com 133 fragmentos; da quadrícula 21Q-21R, 22Q-22R, com 95 fragmentos; da quadrícula 15I-15J, 16I-16J, com 75 fragmentos; da quadrícula S1-S2, T1-T2, com 76 fragmentos; da quadrícula 19A-19B, 20A-20B, com 90 fragmentos. Com eles organizou-se o gráfico a seguir. Os fragmentos muito finos, de 3 a $6 \mathrm{~mm}$, correspondentes a vasilhas Itararé, em grande parte haviam sido retirados das amostras na classificação inicial e, por isso, estão subrepresentados na presente contagem. No gráfico abaixo se vê uma ampla distribuição das espessuras, desde $4 \mathrm{~mm}$ até $24 \mathrm{~mm}$, mostrando os extremos, mas também que a maior representatividade está nos valores médios, com duas saliências, uma entre 8 e $10 \mathrm{~mm}$, outra entre 14 e $15 \mathrm{~mm}$.

\subsection{Pasta e construção}

De modo geral, sem entrar em grandes detalhes, podemos distinguir três tipos de pasta.

Pasta com grãos de hematita: os grãos de hematita, negros e arredondados, podem aparecer sob a forma de areia fina, média ou grossa, até de pequenos seixos dispersos; mais raramente estão misturados fragmentos angulosos de cor marrom. A hematita é natural do lugar e nasce da decomposição do basalto, que 


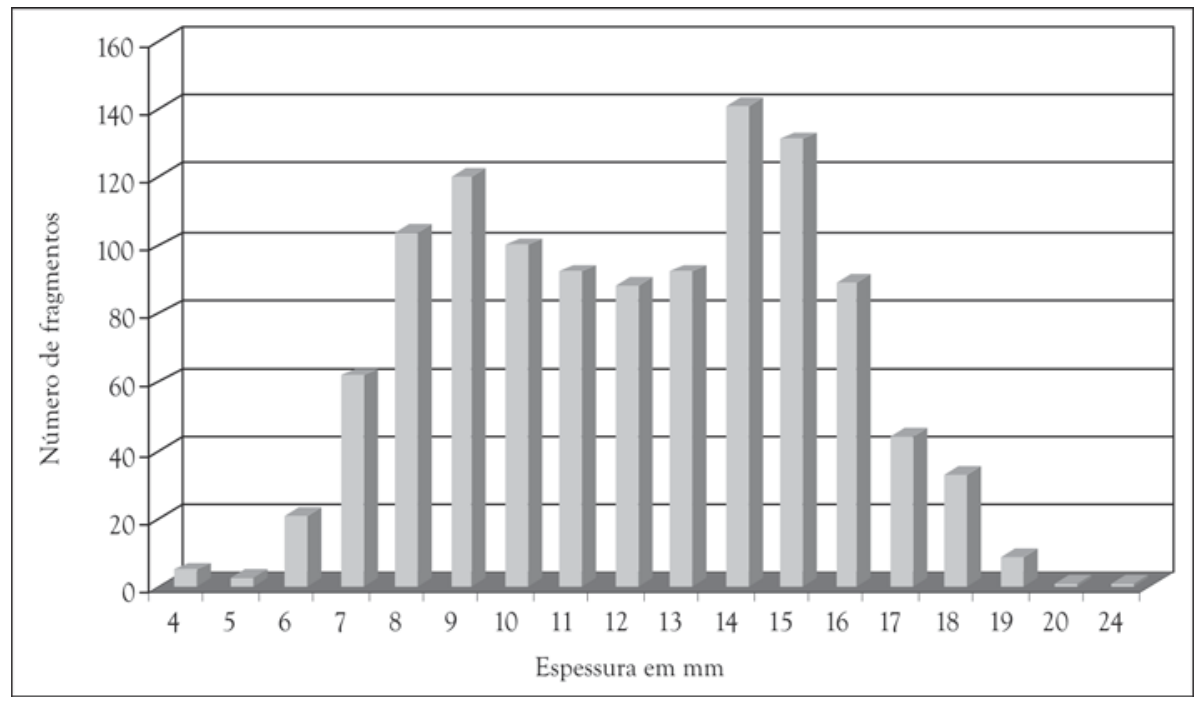

deixa todo o solo vermelho. Especialmente em recipientes grandes, destinados ao uso sobre o fogo, ela pode ser muito densa, deixando pouco espaço para a argila, assemelhando-se o caco a um pé-de-moleque recheado de amendoim e a pasta como placas ou torrões, sem muita uniformidade. Os grãos aparecem em superfícies levemente erodidas e muitas vezes se desprendem, deixando inúmeras pequenas depressões arredondadas. A densidade diferente na utilização de hematita indica intencionalidade e seleção no seu uso. A utilização intensa de hematita na argila pode servir tanto para a criação de uma pasta mais resistente para recipientes muito grandes, como para fomentar uma boa transmissão do calor do fogo para os alimentos que estão sendo cozidos. As panelas, com isso, tornam-se pesadas, mas resistentes. A superfície dos fragmentos está bem alisada tanto interna como externamente e de cor marrom avermelhado; o núcleo é escuro. A parte oxidada apresenta espessuras diferentes nas paredes, sendo geralmente maior na superficie externa. Ela resulta de uma cocção oxidante incompleta e da presença da hematita. Junto com a hematita pode ser usada certa quantidade de cariapé; se ele for mais abundante, a superfície cozida torna-se mais acinzentada e mais leve.

Pasta com cariapé: o cariapé, nos fragmentos em que é denso, se torna visível com um aumento de 20 vezes, como pequenos filamentos ou gomos brancos, no meio de uma massa uniforme de cor cinza. Nas tigelas, nas formas Itararé e nas vasilhas duplas, ele costuma ser denso, produzindo massa fina, uniforme e leve. Geralmente ele vem acompanhado de certa quantidade de grãos de hematita, mas pode também ser exclusivo. Os recipientes com muito cariapé, mesmo quando a parede é grossa, mantêm-se leves. A cor das paredes costuma ser cinzenta, até bastante escura, tornando-se mais marrom se há muita hematita. Os núcleos das paredes são escuros, destacando-se da pequena camada oxidada que é mais amarelada.

Pasta com areia quartzosa: Cristais de quartzo de pequeno tamanho, angulosos, aparecem em certo número de fragmentos de formas itararé. Alguma vez acompanha um pouco de cariapé. As demais características são parecidas com as formas itararé com uso de cariapé.

Novamente, os antiplásticos correspondem aos da tradição Aratu de Goiás; no Planalto Central, em vez de hematita, era freqüentemente usado quartzo e feldspato. A areia fina de vasilhas itararé se destaca no conjunto.

A construção das vasilhas não está muito clara. Embora possamos supor que as panelas grandes tenham sido produzidas com a sobreposição de roletes, nos fragmentos não se percebem quebras que confirmem este uso; a pasta é muito compacta, cheia de grânulos de hematita e às vezes recortada em forma de torrões. Em algumas bases é possivel ver placas sobrepostas, 
mas deduzir que a produção dos grandes recipientes, muito regulares e bem acabados, tenha sido por sobreposição de placas não parece realista. Nos fragmentos correspondentes aos recipientes com muito cariapé, ou naqueles de areia quartzosa, como as paredes são finas, a técnica dos roletes seria ainda mais difícil, mas talvez necessária, seguida de um alisamento rigoroso. Nas formas correspondentes à tradição Itararé pode-se pensar no "paleteado", que consistiria em bater a superfície externa segurando a parede com um suporte interno (Cláudia Inês Parelada, com. pes. 2007). Há necessidade de maior estudo para entender o tipo de produção da cerâmica de Apucarana.

$\mathrm{O}$ acabamento interno e externo, em todas as formas, costuma ser muito bom, com as paredes lisas e talvez as paredes internas inicialmente polidas, especialmente nas formas com cariapé. $O$ leve desgaste das superfícies, em conseqüência do longo uso do terreno, torna difícil dizer se, em algumas formas, também havia brunido. Algumas peças são bastante escuras e outras têm partes mais escurecidas. Nas vasilhas grandes o fundo interno é bem mais escurecido, ocupando, às vezes, a metade da espessura. Aparentemente isto se deve à penetração de substâncias durante o cozimento de alimentos.

As paredes são diretas, não reforçadas; o desenvolvimento delas é natural, as inflexões são suaves, sendo raros os ângulos.

Nas vasilhas grandes, as bases podem estar um pouco reforçadas, mas de forma natural, sem chamar atenção.

No conjunto do material cerâmico percebese que ele é muito parecido com o da tradição Aratu de Goiás. Por isso chama bastante atenção o grupo de vasilhas da tradição Itararé, que à primeira vista se distingue pelos elementos da forma, mas também, parcialmente, pelo antiplástico. $\mathrm{O}$ conjunto desses elementos sugere que também a função tenha sido diferente.

\section{O material lítico}

O material lítico é muito menos numeroso que a cerâmica. Ele é produzido em basalto, diorito, riolito, arenito e calcedônia.

\subsection{Mãos de pilão em basalto (Fig. 6, F-N)}

$\mathrm{Na}$ coleta estão representadas oito mãos de pilão, das quais sete são cilíndricas (G-N) e a oitava mais cônica $(F)$; esta última serviu, ao mesmo tempo, de "quebra-coco". As primeiras sete são de basalto, de coloração cinza mais claro a cinza mais escuro. No acabamento, elas tiveram, primeiro, um martelado fino, que nivelou as superfícies, seguido de cuidadoso polimento, com movimentos no sentido do comprimento da peça, que resultaram em facetas longitudinais, às vezes mais aparentes, geralmente apenas perceptiveis com determinada incidência da luz. O basalto usado era de composição fina e regular, provavelmente colunar, mas não se percebem vestígios de córtex. A oitava mão de pilão foi feita sobre arenito silicificado de granulação grossa que também teve bom acabamento; ela apresenta em cada face uma depressão elíptica rasa e, nos lados, depressões menos marcadas e mais rasas. As mãosde-pilão cilíndricas se assemelham às da tradição Taquara/Itararé, a oitava tem similares nos sítios Aratu de Goiás.

Com exceção da oitava, que é inteira, as demais estão quebradas predominantemente pela ação do fogo, resultando em fraturas em ângulo de $90^{\circ}$, cuja origem pode ser, geralmente, atribuída às roças ou desmatamentos, mas também a variados golpes, redundando em superfícies de fratura rugosas. $\mathrm{O}$ mesmo se observa nos sítios da tradição Taquara/Itararé.

Provavelmente as peças inteiras eram bastante longas, embora não muito grossas. $\mathrm{O}$ estado fragmentário em que se encontram, tratando-se geralmente de fragmentos mesiais, só uma terminal, não permite calcular o tamanho original, nem sua extremidade proximal.

Não há restos de sua produção no sítio, como poderiam ser lascas de preparação ou grandes núcleos, nem mesmo colunas de basalto que seriam usadas como suporte.

A seguir, são descritas as peças do sítio.

Fragmento distal, s.n., da coleta da escola. Forma sub-cilíndrica, perfil transversal tendendo a elíptico por causa de pequena faceta longitudinal em ambas as faces, em razão de o suporte ter sido mais largo que grosso (uma coluna de 
basalto?). A base (extremidade distal) conservada é levemente convexa, com marcas de impacto produzidas com o esmagamento de materiais mais duros que o basalto, possivelmente pequenos grãos de quartzo ou hematita. Uma das facetas também sofreu semelhantes impactos (Fig. 6, H). Comprimento: $7,70 \mathrm{~cm}$; perfil no meio: $4,80 \times 3,80 \mathrm{~cm}$; na base: $4,40 \times 4,10 \mathrm{~cm}$.

Fragmento mesial, s.n., da coleta da escola, em basalto quase preto. As duas extremidades resultaram de fratura possivelmente intencional, mas a superfície delas é rugosa. A partir de uma das extremidades foram tiradas pequenas lascas. Dois golpes na superfície polida tiraram lascas irregulares, que deixaram cicatriz áspera (Fig. 6, M). Comprimento: $8,60 \mathrm{~cm}$; diâmetro: $4,90 \mathrm{~cm}$. Perfil perfeitamente circular.

Fragmento mesial, s.n., da escola. As duas extremidades parecem quebradas intencionalmente (Fig. 6, L). Comprimento: 6,50 cm; diâmetro: $4,10 \mathrm{~cm}$. Perfil perfeitamente circular.

Fragmento mesial, s.n., da escola. As duas extremidades quebradas intencionalmente. Quase a metade da superfície está descascada pela ação do fogo (Fig. 6, N). Comprimento: $3,70 \mathrm{~cm}$; diâmetro: $5,00 \mathrm{~cm}$.

Fragmento mesial, s.n., da escola. Uma das extremidades está quebrada quase reta, a outra é cônica, ação do calor do fogo (Fig. 6, J). Comprimento: $4,50 \mathrm{~cm}$; diâmetro: $4,50 \mathrm{~cm}$.

Fragmento mesial, s.n., da escola. As duas extremidades estão quebradas planas; está rachado longitudinalmente, aproximadamente ao meio das facetas longitudinais bifaciais. $\mathrm{Na}$ extremidade de uma das facetas, junto à quebra longitudinal aparece um resto de pigmento vermelho também polido. Nesta mesma faceta, ao longo de quase toda a extensão, temos descascamento pelo fogo. Por causa das facetas, em ambas as faces, o diâmetro não é perfeitamente circular, mas um pouco achatado, quase elíptico (Fig. 6, G). Comprimento: 16,20 cm; diâmetro original numa extremidade: $4,80 \mathrm{~cm}$; $5,00 \mathrm{~cm}$ na outra extremidade.
Fragmento mesial, SCI 10544, da quadrícula C9/C10-D9/D10. Fraturas retas em ambas as extremidades. Quase a metade da superfície está descascada pelo fogo (Fig. 6, I). Comprimento: $5,60 \mathrm{~cm}$; diâmetro: $4,80 \times 4,50 \mathrm{~cm}$.

Outro fragmento mesial da mesma, SCI 1300, Q3, com quebras recentes (arado, trator?). Comprimento: $2,40 \mathrm{~cm}$.

Mão de pilão/quebra-coco, s.n., da escola. Em arenito silicificado grosseiro, perfeitamente formatada. Em cada uma das duas faces maiores tem depressões alongadas com alguns milímetros de profundidade. Nos dois lados tem depressões parecidas, um pouco mais rasas (Fig. 6, F). Comprimento: $15,70 \mathrm{~cm}$; largura $5,70 \mathrm{~cm}$; espessura: $4,60 \mathrm{~cm}$.

Mão de pilão, lasca pequena polida de basalto. Cat. 2096.

Mão de pilão, fragmento bem polido (sem picoteamento). Cat. 0633.

Mão de pilão, fragmento bem polido. Cat. 0643.

Mãos de pilão aparecem pouco nos sítios da tradição Aratu. Elas existem em Goiás (Schmitz et al. 1982), mas são pequenas, picoteadas e irregulares, em nada parecidas com as de Apucarana.

\subsection{Lâminas de machado em basalto e diorito (Fig. 6, A-E)}

Lâmina de machado em basalto fino, semelhante ao das mãos-de-pilão, s.n., da escola. Perfeitamente formatado e polido, petaloide, não se vendo sinais de picoteamento anterior. Finas estrias longitudinais em ambas as faces. Talão típico bem acabado, medindo 3,90 x 2,10 $\mathrm{cm}$, polido, com sinais de golpes. Num segundo momento a lâmina foi reciclada, retirando o gume polido com dois golpes na mesma face, criando um novo gume, com uma face polida (original) e a outra com duas cicatrizes de lascamento. Provavelmente foi também neste 
momento que se acrescentou um gargalo picoteado, raso, de $2,50 \mathrm{~cm}$ de largura, que dista aproximadamente $3,00 \mathrm{~cm}$ do talão. A peça final mede $12,80 \mathrm{~cm}$ de comprimento; $6,10 \mathrm{~cm}$ de largura máxima; $3,40 \mathrm{~cm}$ de espessura máxima (Fig. 6, C).

Lâmina de machado em basalto fino, perfeitamente polido, s.n., da escola. Quebrado intencionalmente perto da parte distal, antes do adelgaçamento para o gume. Partindo da fratura foram dados golpes em ambas as faces, talvez para criar um novo gume, mas sem sucesso. Não há marcas de fogo. A parte proximal está preservada, terminando num talão polido, medindo $4,40 \times 2,70 \mathrm{~cm}$. A peça remanescente mede $11,60 \mathrm{~cm}$ de comprimento por $6,80 \mathrm{~cm}$ de largura e 4,10 cm de espessura máxima (Fig. 6, A).

Lâmina de machado em basalto fino, perfeitamente polido, parte mesial, s.n., da escola. Ambas as extremidades foram quebradas pelo fogo e uma das faces foi descascada pelo mesmo. 8,70 cm de comprimento; 9,30 cm de largura; 4,70 cm de espessura máxima (Fig. 6, B).

Lâmina de machado em diorito, perfeitamente polida, composta por gume e parte do corpo. Quadrícula C9/C10 - D9/D19. O gume apresenta pequenas mossas e brilho em ambas as faces com uns $5 \mathrm{~mm}$ de largura. Comprimento: $6,70 \mathrm{~cm}$; largura: $6,70 \mathrm{~cm}$; espessura remanescente: $3,40 \mathrm{~cm}$ (Fig. 6, D).

Lâmina de machado em basalto, perfeitamente polida, talão, s.n., da escola. Quebrada intencionalmente. Comprimento: $4,00 \mathrm{~cm}$; largura: 4,50 cm; espessura: $3,70 \mathrm{~cm}$. Talão polido: 2,90 x 2,60 cm (Fig. 6, E).

Lâmina de machado em basalto, parte mesial, s.n., da escola. Quebrada pelo fogo e com marcas de fogo na superfície. Comprimento: $6,00 \mathrm{~cm}$; largura: 2,50 cm; espessura: $3,80 \mathrm{~cm}$.

Lâmina de machado em basalto polido, um pouco mais que a metade de um gume, quebrado intencionalmente. Cat. 10218. Medidas: 3,00 x 4,90 x 3,10 cm.
Lâmina de machado em basalto polido, lasca de perto do gume. SCI-1299. Coleta superficial Q3.

Fragmento irregular: $6,90 \mathrm{~cm} \mathrm{x} \mathrm{6,90} \mathrm{cm} \mathrm{x}$ $3,20 \mathrm{~cm}$.

Lâmina de machado em basalto polido, pequena lasca, próxima do talão. Cat. 10338 (Q2): 4,20 x 2,80 x 0,0361 pés.

Lâmina de machado em basalto polido, talão bem acabado, com pequenas cicatrizes de lascamento (golpes antigos) a partir do talão, SCI-1296, coleta superficial Q3. Comprimento: 2,40 cm; largura: 4,70 cm; espessura: $3,40 \mathrm{~cm}$. Talão: $2,80 \times 2,20 \mathrm{~cm}$.

Lâmina de machado em basalto, lasca intencional, bem polida. SCI-8428. A-14. Medidas: 4,00 x 3,10 x 1,50 cm.

Lâmina de machado em preparo, basalto, SCI-0615, coleta superficial Q3. Lasca semicortical, com uma parte de córtex (estreita, no sentido longitudinal); no vértice há uma pequena superfície que parece polida. Comprimento: $6,00 \mathrm{~cm}$; largura: $5,00 \mathrm{~cm}$; espessura: $1,00 \mathrm{~cm}$.

Do mesmo núcleo foi tirada outra lasca semi-cortical, com uma tira do mesmo córtex, na mesma direção, mas sem marcas de polimento. SCI-0618, coleta superficial Q3. Comprimento: $6,50 \mathrm{~cm}$; largura: 4,50 cm; espessura: $2,00 \mathrm{~cm}$.

Lâmina de machado em basalto, lasca de perto do gume, com aproximadamente metade da face polida. SCI-2095, coleta superficial Q2. Tem o mesmo jeito do exemplar SCI-8428. Comprimento: 4,60 cm; largura: 3,70 cm; espessura: $1,50 \mathrm{~cm}$.

Lâmina de machado em basalto avermelhado, parte mesial, quebrada pelo fogo. SCI-6034, quadrícula 15G/15H-16G/16H. Fragmento irregular, medindo 4,40 x 3,70 x 4,00 cm.

Lasca de objeto polido (machado ou mão de pilão). Cat. $5637.3,40 \times 2,50 \times 0,70 \mathrm{~cm}$. 
As lâminas de machado são bem acabadas e simétricas. Juntando os talões, as partes mesiais e os gumes, pode-se reconstituir a forma que presidia a sua fabricação. As lâminas de machado podiam ser recicladas produzindo-se um novo gume lascado ou um gargalo picoteado; nas peças originais não se percebem gargalos, só na peça reciclada.
A rocha usada para sua producão é preferencialmente o mesmo basalto das mãos-depilão; num caso foi usado diorito.

Lâminas de machado semelhantes são encontradas tanto nos sítios Aratu de Goiás, como nos sítios Taquara/Itararé do Planalto Meridional.
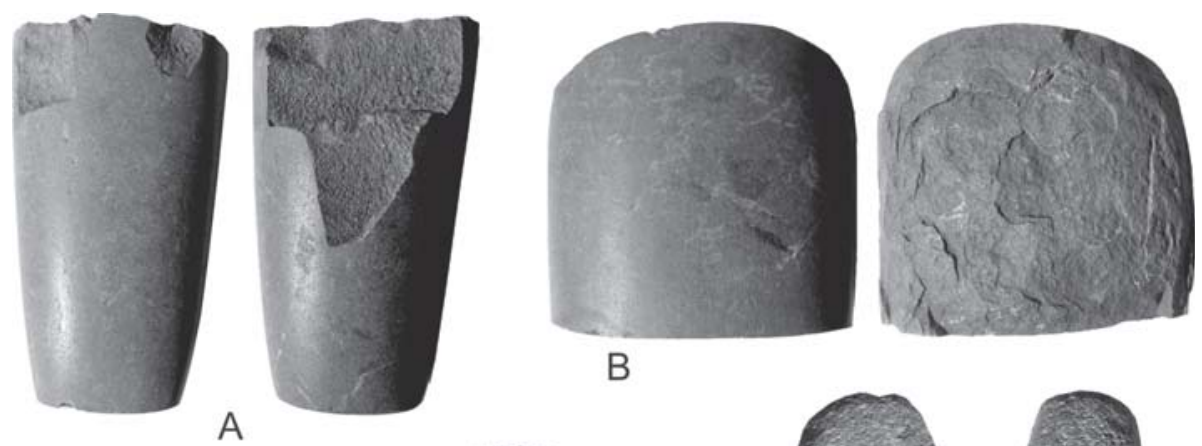

B

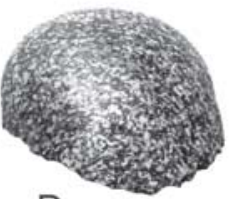

D

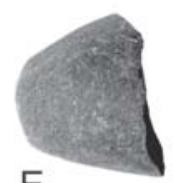

E

C

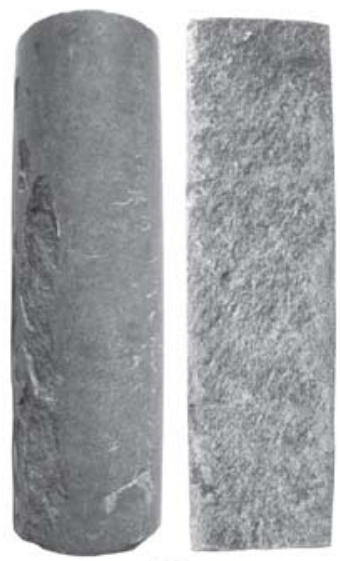

G

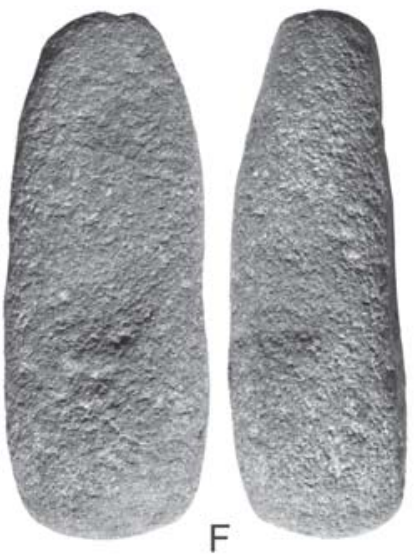

H
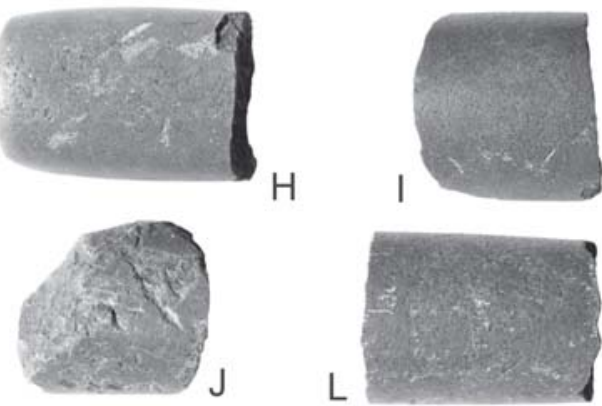

L
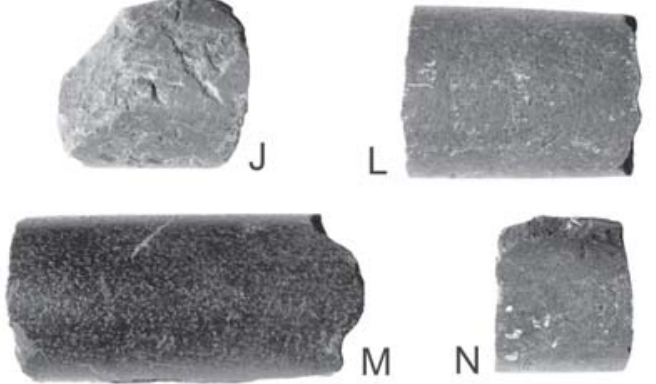

$\mathrm{N}$

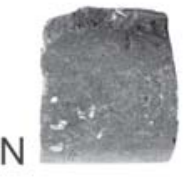

$5 \mathrm{~cm}$

Fig. 6. O material lítico do sítio: A-E lâminas de machado; F-N mãos de pilão. 
Há poucas lascas, que pudessem sugerir produção local das lâminas e também das mãos de pilão. Esta ausência poderia ser tomada como indício de que as peças não eram feitas na aldeia.

\subsection{Outras peças em basalto}

Foram recolhidos ainda: duas lascas secundárias, dois pequenos núcleos cúbicos, três seixos de basalto, um deles possível percutor, outro quebrado pelo fogo, o terceiro natural.

\subsection{Material em riolito e rocha semelhante}

Na coleção existem os seguintes materiais: um raspador terminal, $6,90 \times 5,20 \times 3,40 \mathrm{~cm}$; um núcleo/talhador bifacial, parcialmente cortical, $7,10 \times 7,30 \times 5,50 \mathrm{~cm}$; uma lasca secundária com microlascamento em dois bordos transversais contíguos, 3,60 x 4,40 x 1,60 $\mathrm{cm}$; uma lasca secundária, com microlascamento longitudinal, $3,50 \times 2,90 \times 1,30 \mathrm{~cm}$; uma lasca com dorso, secção triangular, com um bordo retocado. 4,70 × 3,00 x 1,70 cm; 16 lascas secundárias pequenas; duas lascas pequenas corticais; nove núcleos pequenos; quatro pequenos fragmentos. Ao todo são 36 peças.

$\mathrm{O}$ riolito aparece sob a forma de seixos com fino córtex. Como ele é vermelho, pode estar ligado à terra vermelha da área. Ele era retalhado, resultando em pequenas lascas, fragmentos, núcleos muito esgotados. Eventualmente, todos os produtos podiam ser usados.

\subsection{Arenito Botucatu}

Um fragmento de polidor bifacial com as faces um pouco abauladas e bem polidas, os lados quebrados por golpes, 5,40 x 3,90 x 2,00 $\mathrm{cm}$; um pequeno fragmento de polidor unifacial, bem polido, 2,60 x 1,40 x 0,90 cm; um fragmento com um lado liso o outro áspero, 4,30 x 3,10 x 2,30 cm; uma lasca secundária de arenito silicificado com marcas de uso no bordo transversal, 2,50 x 2,70 x 0,80 cm. O arenito Botucatu podia ter sido usado na produção e terminação das bonitas peças polidas em basalto.

Alisadores semelhantes também aparecem nos sítios Aratu de Goiás (Schmitz et al. 1982).

\subsection{Utilização da calcedônia}

Nesta matéria prima aparecem seixos, núcleos, lascas e fragmentos com ou sem uso. A produção de artefatos a partir da matéria prima, que aparece sob a forma de pequenos e médios seixos resistentes, costuma ser feita por retalhamento bipolar, apoiando o seixo a ser percutido num suporte duro e batendo na outra face. Os golpes resultam em fragmentos, lascas e núcleos com relativa uniformidade. Os fragmentos e lascas, às vezes até os núcleos, freqüentemente apresentam bordos aproveitáveis.

Dois seixos: uma drusa alongada cheia de pequenos cristais, com uma das extremidades batida (percutor?), 6,10 x 4,30 x 3,50 cm; um seixinho de quartzo com as duas extremidades batidas, formando bisel, 2,80 × 2,00 × 1,70 cm.

Os pequenos núcleos são 25, geralmente explorados da borda da drusa para o centro, onde costumam quebrar. Às vezes a força do golpe atravessava a drusa tabular de lado a lado. O retalhamento bipolar produzia lascas e fragmentos menores e maiores; aos maiores classificamos como núcleos. Amostras de tamanho: $3,50 \times 3,60 \times 2,30 \mathrm{~cm} ; 2,50 \times 2,70 \times$ $2,00 \mathrm{~cm} ; 2,80 \times 3,00 \times 1,50 \mathrm{~cm} ; 4,00 \times 4,80 \times$ $1,50 \mathrm{~cm}$.

As lascas e fragmentos podem apresentar marcas de uso e ulterior modificação, ou ficar sem estas marcas.

Sem marcas de uso contamos 44 pequenos fragmentos e lascas.

Com marcas de uso contamos 40 pequenas lascas, fragmentos e núcleos (Fig. 7), resultantes de retalhamento bipolar. Geralmente têm talão cortical, forma aproximadamente triangular, bordos naturalmente cortantes. Algumas vezes esses bordos sofreram pequena regularização para melhorar ou modificar o gume, produzir uma ponta ou furador, até facilitar a preensão, mas seu uso é expedito, para uma só utilização. As marcas de uso, sob a forma de microlascamento ou leve embotamento, se encontram em bordos longitudinais, mais raramente em bordos transversais ou em pontas. Amostras: lasca com bordo transversal usado, $2,10 \times 1,60 \times 0,70 \mathrm{~cm}$; lasca com grande bordo longitudinal e transversal parcialmente embota- 

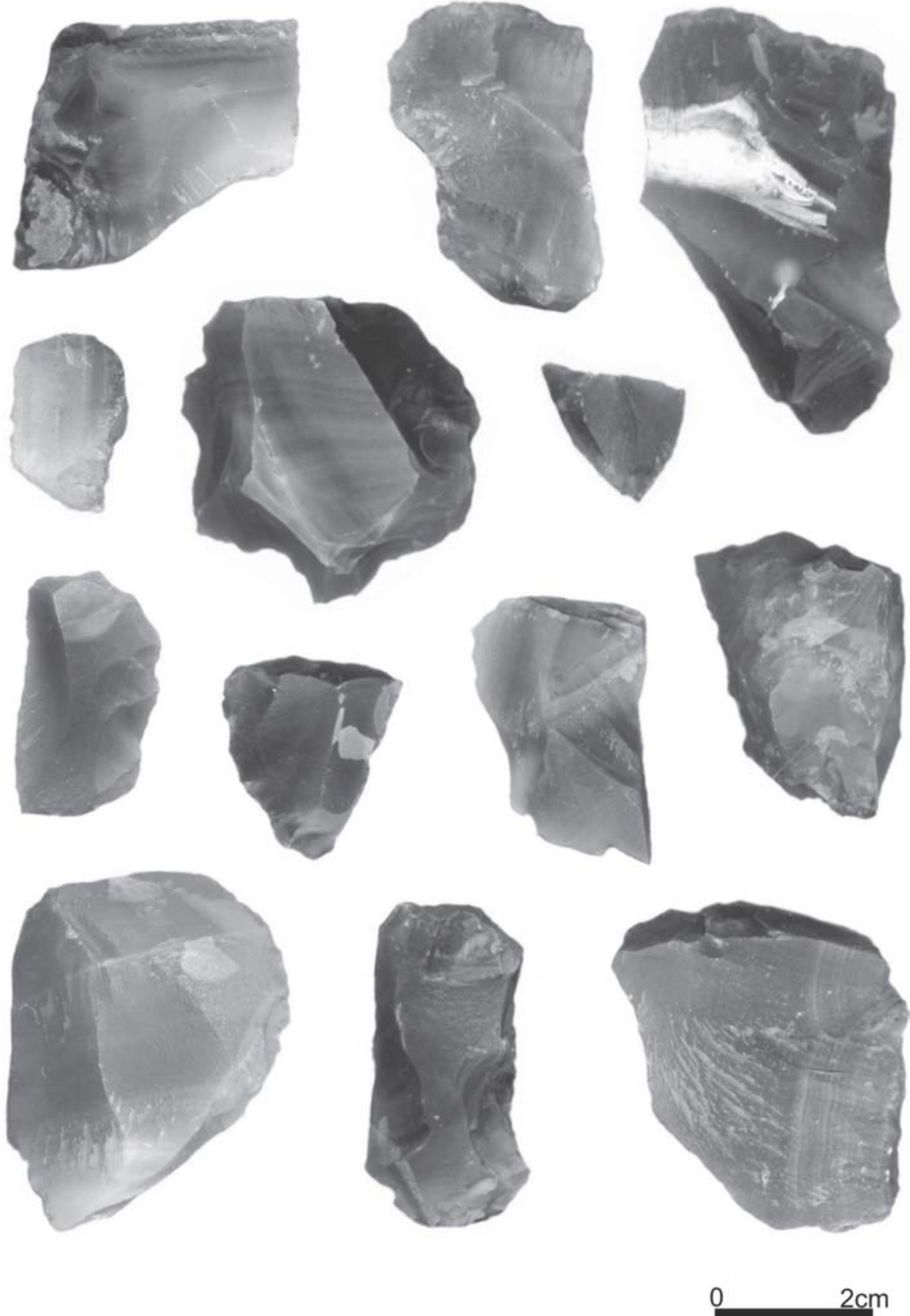

$2 \mathrm{~cm}$

Fig. 7. Pequena amostra de lascas, fragmentos e pequenos núcleos de calcedônia, com marcas de uso ou retoque.

do, parcialmente com microlascamento, $3,30 \mathrm{x}$ $2,50 \times 0,50 \mathrm{~cm}$; lasca secundária com bordo longitudinal regularizado e com microlascamento; lasca com dois bordos longitudinais com microlascamento e ponta aguda em furador, $2,70 \times 2,70 \times 1,10 \mathrm{~cm}$; fragmento elíptico formatizado como enxó, com bordo transversal com marcas de uso, 4,10 x 2,30 x 1,10 cm; 
núcleo bipolar com vértice retocado em ponta grossa, 5,70 × 3,20 x 1,60 cm; fragmento grosso com bordo longitudinal com retoque abrupto, criando gume de raspador e ponta grossa no vértice com o talão, 3,50 x 2,80 x 1,80 cm.

A calcedônia usada vem de drusas originadas do basalto. Ela apresenta diferentes cores desde chumbo até cera, mas não é muito vistosa, predominando matizes de cinza, pardo e cera, geralmente em bandas ou faixas. Ela é de boa qualidade e raramente vem meteorizada. Não se conhece onde ela foi recolhida, se no córrego próximo ou num rio maior. O pequeno tamanho das lascas, fragmentos e núcleos indica que as drusas, de que eles se originaram, não eram grandes; raramente aparecem cristais correspondentes ao centro da drusa.

O material era usado com bastante eficiência: 42 lascas e fragmentos $(37,83 \%)$ apresentam marcas de uso; 44 fragmentos e lascas (39,63\%) não têm marcas evidentes de utilização; 25 (39,63\%) são núcleos.

Material semelhante, em calcedônia, aparece, em pequenas quantidades, nos sítios Aratu de Goiás e é freqüente nos sítios Itararé do Sul do Brasil.

\subsection{Avaliação geral do material lítico}

Percebe-se uma forma definida de produção e uso do material lítico.

O basalto de fina granulação, eventualmente diorito e arenito silicificado, é usado para produzir mãos de pilão e lâminas de machado, sempre muito cuidadosamente acabadas, as primeiras por um rigoroso picoteamento seguido de polimento, os segundos só com alisamento e polimento. Estes artefatos têm morfologia padronizada. Com exceção de uma mão de pilão em arenito silicificado muito tenaz, e uma lâmina de machado reciclada, as peças foram quebradas e destruídas intencionalmente, ou por fogo, nas sucessivas utilizações do terreno pelo homem branco, que plantou a área durante 20 anos e depois a reflorestou, com o que, muitas vezes, terá submetido a superfície do terreno a queimadas. A mão de pilão que está conservada é diferente das demais pela matéria prima, forma e uso, não tendo só função ativa, mas também passiva como base para esmagamento. A lâmina de machado inteira foi reciclada, com a intenção de produzir um novo gume lascado e um raso gargalo picoteado para novo encabamento.

Aparentemente nem as mãos de pilão, nem as lâminas de machado foram produzidas no local da aldeia porque não foram encontrados vestígios que testemunhassem o trabalho preparatório, como seriam as lascas de redução dos suportes. Estes deveriam ser bem grandes e supõem a existência de um afloramento de rocha não intemperizada.

O basalto não era usado para produzir instrumentos lascados porque não produz gumes cortantes duradouros

O riolito, de origem semelhante à do basalto e que produz bordos mais cortantes, foi usado para produzir pequenas lascas e eventuais instrumentos lascados. Como não ocorre em blocos grandes, mas em seixos relativamente pequenos, sua utilidade não teria sido grande. De fato não foi muito utilizado.

A calcedônia, formada no basalto da região, proporcionou os gumes cortantes necessários no cotidiano da aldeia. Ao contrário dos artefatos em basalto, que produziram instrumentos permanentes e de longa duração, a calcedônia fornecia instrumentos expeditos, de fácil produção quando necessários, de uso imediato, descartados depois da primeira utilização.

O arenito Botucatu, bastante consistente, com grande densidade de cristais arredondados, poderia ser um abrasador de primeira qualidade na produção de artefatos polidos.

\section{Considerações finais}

Reunindo os dados expostos no corpo do trabalho fica bastante claro que, em Apucarana, temos um sítio da tradição cerâmica Aratu, com presença de elementos da tradição cerâmica Itararé. As formas e tamanhos da maior parte da cerâmica, os pequenos recipientes duplos e as bases perfuradas, além do intenso uso de cariapé na preparação da pasta são elementos ligados a essa tradição, como ela aparece no interior do Brasil. Por outro lado, as formas e pequenos tamanhos de outra parte da cerâmica, são 
inconfundivelmente Itararé. No material lítico existem elementos que podem ser considerados universais na área, como as lâminas polidas de machado, os quebra-cocos, os percutores, as mãos, as lascas unipolares e o retalhamento bipolar. O que aproxima especialmente as mãos de pilão da tradição Itararé é o seu grande tamanho e perfeito acabamento, diferentes daqueles do Planalto Central, onde elas são pequenas e (mal) acabadas por picoteamento. A composição do material, tanto cerâmico quanto lítico, indica que não se trata simplesmente de uma justaposição ou sobreposição de material. Na cerâmica, o uso de cariapé como antiplástico nas formas Itararé; no lítico, o tamanho e acabamento das mãos de pilão indicam fusão de técnicas que, por sua vez, sugerem um entrosamento da população que vivia na aldeia, composta por populações atribuídas ao Planalto Central e de populações do Planalto Meridional. O estado em que se encontrava o sítio e a maneira como se fez a recuperação não permite dizer se materiais diferentes ocupavam lugares diferentes na aldeia.

A implantação do sítio num interflúvio, em terreno ondulado, de grande fertilidade, coberto por vegetação arbórea densa, limitando com pequena mancha de Cerrado e na proximidade de mata de Araucária, se parece com o padrão Aratu do Planalto Central, de Minas Gerais e de São Paulo. Essa implantação também não destoa da tradição Itararé.

Apucarana é, por enquanto, o ponto mais avançado da tradição Aratu em direção ao sul, afastando-se bastante dos sítios mais próximos, que estão no norte, nordeste e leste de São Paulo. Com este assentamento o grupo passou a fazer limite com novo ambiente, território de outro grupo Jê, que não mais se baseia em cultivos tropicais, mas na coleta do pinhão da Araucária, na caça e em algum plantio. Também o padrão de instalação predominante nesse outro grupo é diferente: em vez de grandes casas superficiais, dispostas em círculo, da tradição Aratu, "casas subterrâneas", especialmente em altitudes em que o pinheiro era abundante.

Podemos perguntar o que levaria um grupo de pessoas da tradição Aratu a se estabelecer tão longe dos outros assentamentos conhecidos. A resposta é prematura, mas tentadora: a varieda- de de recursos da natureza. Na maior parte dos sítios do interior, o ecótono floresta-cerrado possibilitava abundância de recursos criados e apropriados. Em Apucarana o cerrado era menor e talvez mais afastado, mas no outono o pinheiro-do-Paraná oferecia imensa riqueza de saborosas e nutritivas sementes. A união ou colaboração com populações desse novo espaço traria vantagens para ambos os grupos: de certa maneira, recomporia a riqueza do ambiente de origem dos adventícios, e ao grupo associado daria acesso a mais produtos agrícolas.

Na proximidade do sítio Aratu de Apucarana ainda não se conhecem sítios da tradição Itararé, nos quais poderiam surgir as pessoas do contato, mas esta ausência pode ser vencida quando a pesquisa for intensificada. Nos vales dos grandes rios da área, que são o Tibagi, o Ivaí e o Paranapanema, foram estudados sítios da tradição cerâmica Tupiguarani, mas no sítio em estudo não existe nenhum indício de contato com eles.

O sítio Aratu de Apucarana foi encontrado por acaso e ainda está isolado, o que poderia corresponder a um padrão de assentamento semelhante ao observado no norte, nordeste e leste de São Paulo. Mas resulta, mais provavelmente, de falta de pesquisa na área porque o ambiente entre os sítios de São Paulo e o do norte do Paraná, seria favorável para o estabelecimento do grupo.

Nos mapas etnográficos de Nimuendajú e de Peret não aparece, para o norte do estado do Paraná, nenhuma indicação de presença de grupos do cerrado, como seriam os Oti-Xavante, registrados na margem direita do rio Paranapanema ou os Ofaié-Xavante registrados na margem direita do rio Paraná e entre o Tietê e o Grande na margem esquerda do mesmo rio; ou os Kayapó do Sul, que no mapa de Peret, ainda são assinalados na parte central do Estado de São Paulo, onde existem grandes manchas de Cerrado. Acompanhando este ambiente, os antepassados dos Kayapó do Sul, ou de outro grupo semelhante, poderiam ter chegado até o norte do Paraná, onde encontrariam outras populações do tronco lingüístico Jê, com as quais estabeleceriam contatos. Dificilmente essas populações saltariam do norte de São Paulo 
para o norte do Paraná sem ocupar os espaços intermédios.

A cronologia do sítio, do século XIV/XV da era cristã, corresponde ao momento em que a tradição Aratu, assim como é estudada pelos arqueólogos, alcançaria sua máxima expansão no Nordeste, no Planalto Central, no Sudeste, até seu limite no Sul do Brasil. Ao tempo da conquista européia, as populações descendentes deveriam ser conhecidas por nomes diferentes, que não faziam referência aos elementos materiais que o arqueólogo usa para falar de seu passado.

SCHMITZ, P.I.; ROGGE, J.H. A site of the Aratu ceramic tradition in Apucarana, PR. Revista do Museu de Arqueologia e Etnologia, São Paulo, 18: 47-68, 20008.

\begin{abstract}
The paper describes an archaeological site discovered in the city of Apucarana, PR, whose most important objects are typical of the ceramic tradition named Aratu, known from investigations in Central Brazil; but there are also important elements of the ceramic tradition named Itararé, known from studies in South Brazil. The settlement was established on a hill, that divides the waters of three important rivers: the Tibagi, the Pirapó and the Ivaí, tributaries of the Paranapanema River. The climate of the place is sub-hot, the atmospheric precipitation about $1.500 \mathrm{~mm}$, the soil is rich, and the vegetation is tropical forest, bordering a subtropical forest whit Araucaria angustifolia. The site was dated, by AMS, AD 1390-1430, time when the Aratu tradition had established settlements in the Northeast, in the Central-west and in the Southeast of the country, in areas of dense Atlantic forest, in areas of ecological tensions in the "Cerrado" environment and in the tropical forest. To clarify the site's position in the Aratu tradition, the paper recapitulates the most important data about the mentioned culture.
\end{abstract}

Keywords: Apucarana - Aratu site - Contact with Itararé

\title{
Referências bibliográficas
}

AFONSO, M.C.; MORAES, C.A.

2005/2006 O sítio Água Branca: Interações culturais dos grupos ceramistas no norte do Estado de São Paulo. Revista do Museu de Arqueologia e Etnologia, 15/16: 59-71.

ALVES, M.A.

2003 Documentação cerâmica contextualizada e as diferenças de gênero nos sepultamentos primários do sítio de Água Limpa, Monte Alto, São Paulo. Canindé, Revista do Museu de Arqueologia de Xingó, 3: 275-289.

2004 Estratigrafia, estruturas arqueológicas e cronologia do sítio Água Limpa, Monte Alto. São Paulo. Canindé, Revista do Museu de Arqueologia de Xingó, 4: 283-324.
ALVES, M.A.; CHEUICHE MACHADO, L.M. 1995/96 Estruturas arqueológicas e padrões de sepultamento no sítio de Água Limpa, Monte Alto - SP. Anais da VIII Reunião Científica da Sociedade de Arqueologia Brasileira. EDIPUCRS, Porto Alegre, 2: 295-310

ALVES, M.A.; CALLEFFO, M.E.V.

1996 Sítio arqueológico de Água Limpa, Monte Alto, São Paulo - Estruturas de combustão, restos alimentares e padrões de subsistência. Revista do Museu de

ANÔNIMO Arqueologia e Etnologia, 6: 123-140.

2003 A cerâmica indígena do sítio Caçapava I. 
In: Caldarelli, S.B. (Coord.) Arqueologia do vale do Paraíba do Sul. SP-070 Rodovia Carvalho Pinto. DERSA Desenvolvimento Rodoviário S.A.: 214-220.

ATAÍDES, J.M.

1991 Sob o signo da violência: colonizadores e Kayapó do Sul no Brasil Central. Dissertação de Mestrado, Goiânia, UFGO.

BROCHADO, J.P.; CALDERÓN, V.; CHMYZ, I.; DIAS JR, O.F.; EVANS, C.; MARANCA, S.; MEGGERS, B.J.; MILLER, E.T.; NASSER, N.A. DE S.; PEROTA, C.; PIAZZA, W.F.; RAUTH, J.W.; SIMÕES, M.F.

1969 Arqueologia brasileira em 1968. Programa Nacional de Pesquisas Arqueológicas. Publicações Avulsas do Museu Paraense Emílio Goeldi, 12.

CALDARELLI, S.

1999 Levantamento arqueológico em planejamento ambiental. Revista do Museu de Arqueologia e Etnologia. Suplemento 3: 347-369.

2003 Os sítios arqueológicos e as pesquisas. In: Caldarelli, S.B. (Coord.) Arqueologia do vale do Paraiba do Sul. SP-070 Rodovia Carvalho Pinto. DERSA Desenvolvimento Rodoviário S.A.: 8-46.

\section{CALDERÓN, V.}

1969 A fase Aratu no Recôncavo e litoral norte do Estado da Bahía. Publicações Avulsas do Museu Paraense Emílio Goeldi, 13: 161-172.

1971 Breve notícia sobre a arqueologia de duas regiões do Estado da Bahía. Publicações Avulsas do Museu Paraense Emílio Goeldi, 15: 163-177.

1974 Contribuição para o conhecimento da arqueologia do Recôncavo e do sul do Estado da Bahia. Publicações Avulsas do Museu Paraense Emílio Goeldi, 26: 141-154.

CHMYZ, I.

1977 Pesquisas paleoetnográficas efetuadas no vale do rio Paranapanema, Paraná-São Paulo. Boletim de Psicologia e Antropologia 5, Curitiba.

DIAS JR., O.F.

1971 Breves notas a respeito das pesquisas no sul de Minas Gerais. Publicações Avulsas do Museu Paraense Emílio Goeldi, 15: 133-148.

FERNANDES, H.L.A.

2003 Os sepultamentos do sitio Aratu de PiragibaBA. Dissertação de Mestrado, Salvador, UFBA.
GASPAR, M.D.; BARBOSA, M.; CORDEIRO, J.

2007 Arqueologia dos vales dos rios Paraíba do Sul e Guandu. Rio de Janeiro: Museu Nacional, série livros 27.

GEOGRAFIA DO BRASIL,

1977 regiões Nordeste, Centro-Oeste, Sudeste e Sul. Rio de Janeiro: FIBGE. GOMES, D.M.C.

LINSINGER, L. VON; CERVI, A.C.

2008 Taxonomia da família Combretaceae R. Brown nas formações de cerrado do Estado do Paraná, Brasil. Pesquisas, Botânica, 5I9, no prelo.

MAPA ETNO-HISTÓRICO DO BRASIL E REGIÕES ADJACENTES

1980 adaptado do Mapa de Curt Nimuendajú, 1944. Rio de Janeiro: Fundação Instituto Brasileiro de Geografia e Estatística.

MARANCA, S.; SILVA, A.M.; SCABELLO, A.

1994 Projeto Oeste Paulista de Arqueologia do Baixo e Médio Vale do Rio Tietê: Síntese dos trabalhos realizados. Revista do Museu de Arqueologia e Etnologia, 4: 223-226.

MORALES, W.F.

200512.000 anos de ocupação: um estudo de arqueologia regional na bacia do córrego Água Fria, médio curso do rio Tocantins. Tese de Doutorado, São Paulo: USP.

OLIVEIRA, E.R.

2005 Aspectos da interação cultural entre os grupos ceramistas pré-coloniais do médio curso do rio Tocantins. Dissertação de Mestrado, São Paulo: USP.

PERET, J.A.

1971 Mapa etnográfico do Brasil. Índios do passado (1500). S.l., s.ed.

PEROTA, C.

1971 Dados parciais sobre a arqueologia norte espírito-santense. Publicações Avulsas do Museu Paraense Emílio Goeldi, 15: 149-162.

1974 Resultados preliminares sobre a arqueologia da região central do Estado do Espírito Santo. Publicações Avulsas do Museu Paraense Emílio Goeldi, 26: 127-140.

PONTIM, R. DE L.

2004 Configuração do povoamento pré-colonial do norte goiano: o caso dos grupos ceramistas. Dissertação de Mestrado, São Paulo: USP.

\section{ROBRAHN-GONZÁLEZ, E.M.}

1996 A ocupação ceramista pré-colonial do Brasil Central: origens e desenvolvimento. Tese de Doutorado, São Paulo: USP. 
Um sítio da tradição cerâmica Aratu em Apucarana, PR.

Revista do Museu de Arqueologia e Etnologia, São Paulo, 18: 47-68, 2008.

ROBRAHN-GONZÁLEZ, E.M.; AFONSO, M.C.; DE BLASIS, P.A.D.; FIGUTI, L.; NEVES, E.G.; EGGERS, S.

1998 Água Vermelha: pesquisa arqueológica de salvamento. São Paulo: Museu de Arqueologia e Etnologia, USP. 87 p.

ROGGE, J.H.

2005 Fenômenos de fronteira: um estudo das situações de contato entre os portadores das tradições cerâmicas pré-históricas no Rio Grande do Sul. Pesquisas, Antropologia, 62. São Leopoldo: Instituto Anchietano de Pesquisas-UNISINOS.

SCHMITZ, P.I.

1988 As tradições ceramistas do Planalto SulBrasileiro. Arqueologia do Rio Grande do Sul, Brasil. Documentos, São Leopoldo, Instituto Anchietano de PesquisasUNISINOS, 2: 75-130..

SCHMITZ, P.I.; WÜST, I.; COPÉ, S.M.; THIES, U.M.E.

1982 Arqueologia do Centro-Sul de Goiás. Uma fronteira de horticultores indígenas no Centro do Brasil. Pesquisas, Antropologia, 33. São
Leopoldo: Instituto Anchietano de Pesquisas-UNISINOS.

SCHMITZ, P.I. ; BARBOSA, A.S.

1985 Horticultores pré-históricos do Estado de Goiás. São Leopoldo: Instituto Anchietano de Pesquisas-UNISINOS. SCHMITZ, P.I.; VERARDI, I.; DE MASI, M.A.N.; ROGGE, J.H.; JACOBUS, A.L.

1993 Escavações arqueológicas do Pe. João Alfredo Rohr: O sitio da praia das Laranjeiras II. Uma aldeia da tradição ceramista Itararé. Pesquisas, Antropologia, 49.

SIMÕES, M.F.

1984 An ecological model of the spread of pottery and agriculture into eastern South America. Tese de Doutorado, Urban, Illinois.

VIANA, S.A.

1996 Análise espacial intra-sítio: o estudo do sítio Lourenço (GO-CA-14). Revista de Arqueologia, 9: 65-87.

WÜST, I.

1983 Aspectos da ocupação pré-colonial em uma área do Mato Grosso de Goiás. Dissertação de Mestrado, São Paulo: USP. 